\title{
Modern Rune Carving in Northern Scotland
}

\author{
Andrea Freund and Ragnhild Ljosland \\ (University of the Highlands and Islands)
}

\begin{abstract}
This article discusses modern runic inscriptions from Orkney and Caithness. It presents various examples, some of which were previously considered "genuine", and reveals that OR 13 Skara Brae is of modern provenance. Other examples from the region can be found both on boulders or in bedrock and in particular on ancient monuments ranging in date from the Neolithic to the Iron Age. The terminology applied to modern rune carving, in particular the term "forgery", is examined, and the phenomenon is considered in relation to the Kensington runestone. Comparisons with modern rune carving in Sweden are made and suggestions are presented as to why there is such an abundance of recently carved inscriptions in Northern Scotland.
\end{abstract}

Keywords: Scotland, Orkney, Caithness, modern runic inscriptions, modern rune carving, OR 13 Skara Brae, Kensington runestone

\section{Introduction}

$\mathrm{T}$ his article concerns runic inscriptions from Orkney and Caithness that were, either demonstrably or arguably, made in the modern period. The objective is twofold: firstly, the authors aim to present an inventory of modern inscriptions currently known to exist in Orkney and Caithness. Secondly, they intend to discuss the concept of runic "forgery". The question is when terms such as "fake" or "forgery" are helpful in describing a modern runic inscription, and when they are not.

Included in the inventory are only those inscriptions which may, at least to an untrained eye, be mistaken for pre-modern. Runes occurring for example on jewellery, souvenirs, articles of clothing, in logos and the 
like are therefore not included here, but see an article by Ragnhild Ljosland (2014) for a discussion of these. Also excluded are runic inscriptions which are executed on modern buildings or other material structures known to have been constructed in the modern period. An example of this would be the runes written in the concrete of the sea protection wall at the Neolithic village of Skara Brae, Orkney.

By making such a selection, the authors have already assumed some of the distinctions they want to discuss between different types of modern runic inscriptions: some do not attract labels such as "fake" or "forgery" despite their modern origin, as for example in the case of souvenirs. Others may have been produced with an intent to deceive, and therefore more reasonably invite such terminology. The interest, however, lies in the grey area between: modern inscriptions which could be mistaken for pre-modern, due to their location, medium, execution, or text content, but for which there is no evidence that they were deliberately made to deceive. Thus these are perhaps undeserving of labels such as "fake" or "forgery".

In the following, a variety of examples from Orkney and Caithness will be introduced in order to produce a first inventory of such modern inscriptions, which will also demonstrate some of the difficulties that such carvings present even to trained runologists. The inscriptions are arranged geographically, beginning with those situated within the Heart of Neolithic Orkney UNESCO World Heritage Site, progressing to those from the rest of Orkney, and finally concluding with two inscriptions from Caithness.

\section{Modern inscriptions from the Heart of Neolithic Orkney UNESCO World Heritage Site}

OR 13 Skara Brae: a doodle which ended up in Orkney Museum The inscription OR 13 is carved on a stone slab from Skara Brae at the Bay of Skaill on the west coast of Orkney Mainland. The site is known for its Neolithic village. However, there are also Viking Age archaeological remains in the vicinity, the best known of which is the Skaill Hoard, a collection of silver artefacts dating to the 900s. A Viking Age longhouse has also been excavated nearby (Griffiths 2015, 219-36).

Before its true provenance came to light, OR 13 was hailed as "clearly another significant addition to the evidence for the Late Norse period from the general area of the Bay of Skaill" (Morris 1985, 89). However, new evidence has recently been submitted which shows that OR 13 was in fact inscribed in the modern period. 
The traditional narrative for OR 13 holds that it was discovered in 1963 by an Ancient Monuments work squad while repairing the Skara Brae sea protection wall (Barnes and Page 2006, 193 f.). The slab was then split and used for paving, with the incised marks facing down. In 1982, it was recovered by Ancient Monuments workers led by Patrick Ashmore.

The inscription was then read as containing three younger futhark runes and three twig runes. The twig runes, also known as cipher runes, are grouped above the younger futhark runes on the surface of the stone and can be interpreted as $2 / 3,1 / 2$ and $2 / 4$. The system of twig runes rests on the division of the sixteen runes of the younger futhark into three ættir 'families, groups (of eight?)' (1. tbmlk, 2. hnias, 3. fupark). The twigs on each side of the stave indicate the $æ t t$ and the number of the rune within its ætt (Düwel 1998, 566-68). Using this system of encryption, the inscription could be read as iba, which led Ashmore and Ingrid Sanness Johnsen to suggest the male personal name Ívarr. Although not unchallenged (see Barnes and Page 2006, 194, for criticism), this interpretation was accepted by the Orkney Museum and displayed on the stone's interpretation board. Below the cipher runes are three further characters, these not in cipher, which appear as $\mathbf{r} * \mathbf{r}$. They can be interpreted alternatively as three times runic $\mathbf{r}$ or Roman 'R', or twice runic or Roman $\mathbf{r} /$ 'R' with something else in the middle. The middle rune could potentially be read as Roman ' $\mathrm{K}$ ' or runic $\mathbf{p}$. No certain interpretation has been suggested for these three runes (Ashmore and Sanness Johnsen 1984, 183-85; Barnes and Page 2006, 193-97).

Following its 1982 (re-)discovery, the stone slab was donated to the Orkney Museum and incorporated into the permanent exhibition where it was presented as genuine, although Barnes and Page (2006, 196 f.) take a more critical stance: “By and large we are agnostic about OR 13's status as a Viking Age or medieval inscription. There is nothing to mark it out as clearly modern, but there is little to confirm it as early either, beyond the hunch that it was buried under sand for some time. Normally one would not be so insistent on evidence of age, but given the astonishingly high percentage of Orkney twig rune inscriptions, and doubt about the origin of several, scepticism seems justified." Barnes also noted that the oddity of the inscription was an argument for its modern origin, although it is difficult to ascertain the extent to which rune-carvers in Orkney might have deviated from Scandinavian standards (Barnes 2003, $11 \mathrm{f}$.).

However, in 2015, delegates to the Rune Rede colloquium in Orkney (Ninth full-day runic colloquium, 21-23 May 2015) heard new testimony which had come to light about OR 13. In preparation for the Rune Rede, 
Ragnhild Ljosland put together a brochure of all the Orcadian inscriptions with up-to-date information for colloquium attendants and in that connection revisited the inscriptions held by Orkney Museum. It transpired that the Orkney Museum had removed OR 13 from the permanent exhibition and put it in storage after learning from a member of the public some years earlier that it was modern. The story of its production varies slightly according to the different members of museum staff, but the version below is what the authors believe to be the most accurate.

According to the Exhibitions Officer at the Orkney Museum in personal conversation with the authors, a local man approached museum staff in the 2000s and admitted to having produced the inscription. He had worked with a team of Ancient Monuments workers on re-paving a path at Skara Brae in 1982 and in his lunchbreak carved some runes in one of the slabs as a joke for his co-workers. Their supervisor, however, on seeing the runes, thought they were real and instantly contacted the museum; the carver feared disciplinary consequences and did not speak up. Only years later, when he saw his carving in the museum exhibition, did he finally reveal its true provenance to museum staff. It took several more years for the museum to remove OR 13 from its exhibition.

Some uncertainties remain. The museum staff member who originally heard the testimony, curator Anne Brundle, has since passed away, so we are left with the second-hand retelling from staff who heard it from her. It is of course theoretically possible that the story of the confession is invented but it is worthwhile applying Occam's razor to the case: the simplest explanation, and the one requiring the fewest assumptions, would indeed be that the witness was telling the truth and produced the runic inscription in the 1980s. Otherwise, one would have to assume that either the museum staff member or the witness lied, and proceed to find explanations to account for the various unusual traits of the inscription: its position at the lower centre of a large flagstone, its mixing of younger futhark and twig runes, its lack of linguistic meaning, its surprisingly good preservation and its somewhat unusual find spot and backstory.

Nevertheless, and despite all doubts, OR 13 formed part of the Viking and medieval exhibition in Orkney Museum for almost three decades. It was also part of a temporary exhibition on runes in Orkney from the Viking Age to the present in 2019.

OR 5 Ring of Brodgar (lost)

In 1908, Orkney's most famous Neolithic landmark, the Ring of Brodgar Neolithic standing stone circle, contained a single $3 / 4$ twig rune on a loose 
stone which has subsequently been lost. Only a photograph remains and Barnes (2003, 9 f.) suggests the inscription may have been an attempt to copy part of OR 4 . The latter inscription, on stone 13 in the stone circle, is more likely than not to be medieval, as recent discussions with archaeologist Colin Richards suggest that the side of the stone carrying the runic inscription was facing down upon discovery (personal communication, 14 Jan. 2017; see also Downes et al. 2013, 100-04). The standing stone was re-erected in 1908 and the part carrying the runes is now upright against the stump remaining in its socket.

While it is difficult to state anything with certainty about the lost inscription OR 5, it seems most likely that it was modern rather than medieval. The loss of the actual inscription prevents any further research into its genesis, making it impossible to determine conclusively whether the inscription was indeed copied from OR 4, which seems likely, and if so, whether it was copied before the standing stone cracked and fell, burying its inscription in the ground, or after it was retrieved and re-erected.

\section{OR 7 Brodgar farm and a dubious inscription from Stenness}

In addition to those discussed above, there are several other instances of inscriptions from within the Heart of Neolithic Orkney UNESCO World Heritage Site where a Viking Age or medieval origin is at least doubtful. OR 7, on a sandstone block from Brodgar farm, consists of various twig runes which cannot be interpreted in any meaningful way. Brodgar farm occupies the narrow Brodgar peninsula separating the Stenness and Harray lochs, presently home to the Ness of Brodgar Neolithic excavation, and in the past also included the Ring of Brodgar and surrounding fields. The proximity of the find spot to both the Maeshowe chambered cairn with its thirty-three medieval runic inscriptions (Barnes 1994) and the Ring of Brodgar raises further doubts of its Viking Age or medieval origin because the inscriptions there, with many twig runes, could have served as an inspiration for modern copiers (Barnes 2003, 10).

Another potential runic inscription on a stone block from near Stenness Loch is not included in the corpus edition of Scandinavian runic inscriptions of Britain (Barnes and Page 2006). According to Barnes, "if these [carvings] were ever intended as twig-runes, they were carved by an incompetent" $(2003,10)$. Barnes provides no picture of the inscription. It is unclear whether any runic forgery was ever intended but the result has in any case never been classed as a genuine runic inscription. 


\section{Other examples from Orkney}

\section{Cuween Hill}

In 1991, Judith Jesch reported finding two sets of runes inside the Neolithic chambered tomb on Cuween Hill, situated on Orkney Mainland c. $6 \mathrm{~km}$ from Maeshowe: one inscription is carved in plain runes on the south wall and reads inkibiorh. This appears to be a copy of part of the famous inscription OR Barnes 9 from Maeshowe, which features heavily in publications about Maeshowe, for example in the guidebook and on a postcard, and is also represented in a modern artwork at Kirkwall Airport. This, in combination with the fact that Cuween Hill Cairn was filled with rubble until it was excavated in the 1880 s, leads to the assumption that these runes must be modern (Jesch 1991).

The second runic find by Jesch in Cuween Hill Cairn is somewhat more puzzling: the east wall of the chamber bears four twig runes, transliterated as fhmf or fhlf. Arguments in favour of their modernity are again the fact that the tomb was filled with debris and that they are very lightly cut. In examining their potential authenticity, Jesch (ibid., 14) also mentions that "it is unusual (if not unique) to have a modern inscription in cryptic runes" and that "although the inscription is meaningless, the runes are not improbable and were plausibly executed". Michael Barnes (2003, 5), however, argues it is "highly unlikely ... that anyone forced their way into Cuween during the Norse period in Orkney - and had they done, we would surely on the evidence of Maeshowe have expected to find more signs of activity than four small twig-runes with no obvious meaning”. Since Jesch's discovery, several other, most likely modern, twig runes have also turned up in Orkney, including Unstan Tomb (see below for detailed description) and Stenness Loch (see above). Further, twig rune inscriptions that were known and believed to be Viking Age or medieval in 1991 have since been revised and deemed most likely modern, i.e. OR 13, OR 5, and OR 7 (all discussed above). Therefore, it no longer seems strange to find a modern twig rune inscription in Cuween Hill Cairn. The unsupervised tomb is currently freely accessible via a short uphill walk, so that any member of the public could have carved these inscriptions. A recent survey of the tomb by the authors has, however, revealed no further runic inscriptions.

\section{Unstan Tomb: OR 2, more twig runes, and a recent discovery}

Originally classed as genuine and given the number OR 2, the runic inscription inside the Neolithic chambered tomb of Unstan, c. $4.5 \mathrm{~km}$ from Maeshowe, is now generally thought to be modern (Barnes 2003, 7 f.). No 
runes were observed during the original excavations in 1884 . The chambered tomb is freely accessible.

It is not known precisely when the runes or rune-like marks were carved, but Barnes and Page discuss marks noted in the 1934 Royal Commission on the Ancient and Historical Monuments of Scotland (RCAHMS) field notebook and in the 1946 field report, so a genesis at some point in the late 1800 s or early 1900 s is conceivable. The carving features various rune-like symbols and a possible twig rune, with no secure reading having been suggested (Barnes and Page 2006, 338-40).

Interestingly, a recent examination by the authors of the entire tomb, which contains countless graffiti-style carvings from the 1800s to the present, revealed two additional faint carvings that may be twig runes. These are located on a stone approximately one metre to the right of OR 2 and a half metre above the entrance to the single side chamber. As they have never been noticed - or at least published - before, they must be assumed to have been carved very recently. The runes are covered in algae, the growth conditions for which are very favourable: with the tomb situated by a lake, the air inside is humid and light enters through a modern skylight. The presence of algae growth should therefore not be taken as an indicator of age beyond a few months. One attempt to date a runic inscription through the growth of mineral deposits, lichen and algae has been made in the case of the controversial inscription in the Kleines Schulerloch cave in Bavaria. Christian Züchner argues that no new growth has been observed there over the last decades, which he adduces in support of a dating in the migration period $(2006,383)$. However, the authenticity of the carving remains disputed, and as early as 1984 the last surviving witness to its discovery, Hellmut Rosenfeld, argued strongly against using mineral deposits and the slow growth of algae as indicators of age, because in the intervening decades a forest had grown at the cave mouth, reducing humidity and stalling algae growth (1984, 162). In the case of Unstan, algae growth is far more rapid than in the dark cave in the relatively Continental climate of Bavaria and therefore a poor indicator of age. There are also no noticeable mineral deposits on the slabs that contain the inscriptions inside the tomb.

A very tentative reading of these two possible twig runes would be $\mathbf{1} / \mathbf{3}$ $3 / 2$, which, assuming the cipher is the same as that used in Maeshowe, could be transliterated $\mathbf{m} \mathbf{u}$. No apparent meaning suggests itself.

During a renewed visit to the tomb by the authors in May 2017, yet another runic inscription was discovered inside the tomb (see fig. 1). The inscription is lightly incised but readily distinguishable on a large slab 


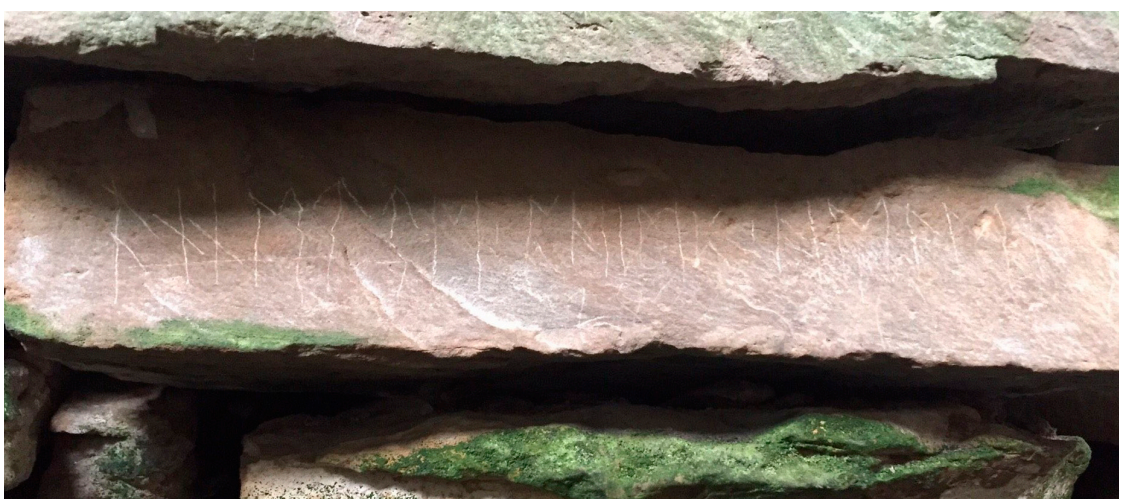

Fig. 1. The latest inscription from Unstan. Photo: Catherine Johnson, 2017.

opposite the entrance to the main chamber. Its eighteen runes (see below) are c. $3 \mathrm{~cm}$ high and cover almost the entire face of the slab, with a length of c. $40 \mathrm{~cm}$. They are c. $140 \mathrm{~cm}$ above the tomb's current floor level. Runes 17 and 18 have been damaged, such that in its present state the inscription appears to read:

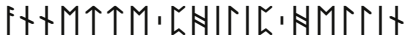

However, archaeologist Antonia Thomas had surveyed the tomb in 2013, before the damage, and took a photo of this section where there is a visible branch connecting runes 17 and 18 ( $(\mathrm{I} \mathbf{~ l i}$ ) in the present apparent reading and transforming them into a single rune: Me (fig. 2).

The original inscription was therefore (with transliteration and interpretation):

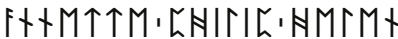

\section{annette:philip:helen}

\section{'Annette Philip Helen'}

As this inscription is undeniably modern, no attempt at an Old Norse or Old English interpretation needs to be made, and the obvious interpretation is that it contains the names Annette, Philip and Helen. The content, the doubling of consonants and the use of runes from the older futhark or

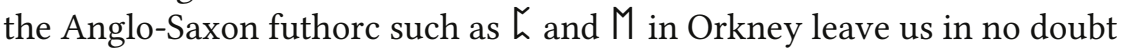
of this inscription's recent genesis. The number 2000 is written below the inscription and may indicate the year of carving. 


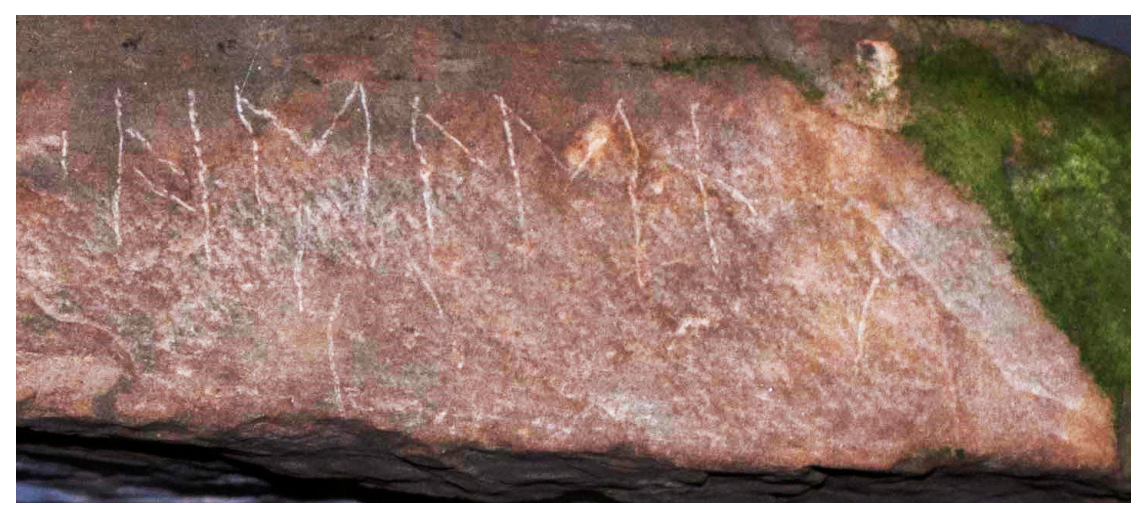

Fig. 2. Unstan, runes 14 to 18 before the damage occurred. Photo: Antonia Thomas, 2013.

\section{Broch of Borwick}

In 2017, the authors undertook a field trip to the Iron Age broch at Borwick, located on a clifftop at Yesnaby on the west coast of Orkney Mainland. The archaeologist Christopher Gee had reported seeing suspected runes in the broch and indeed, in the still-standing entrance passage, a runic inscription was clearly discernible.

The eighteen runes run across a flat stone slab that forms part of the right side wall of the entrance passage. The runic characters cover approximately $50 \mathrm{~cm}$ of the slab, are about $4 \mathrm{~cm}$ in height and deeply incised with a sharp tool (see fig. 3). The same slab also has other incisions, one of which looks like a Roman 'A', and others, below the runes, could possibly be crosses.

\section{MFחRITM:HFHPRI1MR:I1}

It is not immediately obvious which rune-row is intended here. Rune 1, $\mathrm{X}$, belongs to the older futhark and Anglo-Saxon futhorc, while rune 2, F, is diagnostic for the Anglo-Saxon futhorc. The remainder of the inscription evidently mixes rune-rows. The rune forms $\boldsymbol{t} \mathbf{n}$ and $1 \mathbf{t}$ are exclusively used in the Viking Age younger futhark and its medieval descendants, while runes 8 and 10 are single-barred $\mathbf{h}$, which is common in the older futhark but found only in some early Anglo-Saxon futhorc inscriptions. These two runes do not look identical, and rune 10 may also be read as $\mathbf{s}$ while for rune 8 only a reading as $\mathbf{h}$ is plausible. Rune 9 could be an Anglo-Saxon futhorc $æ$ or an older futhark $\mathbf{a}$, depending how the carver has mixed the rune-rows. Tentative transliterations are: 


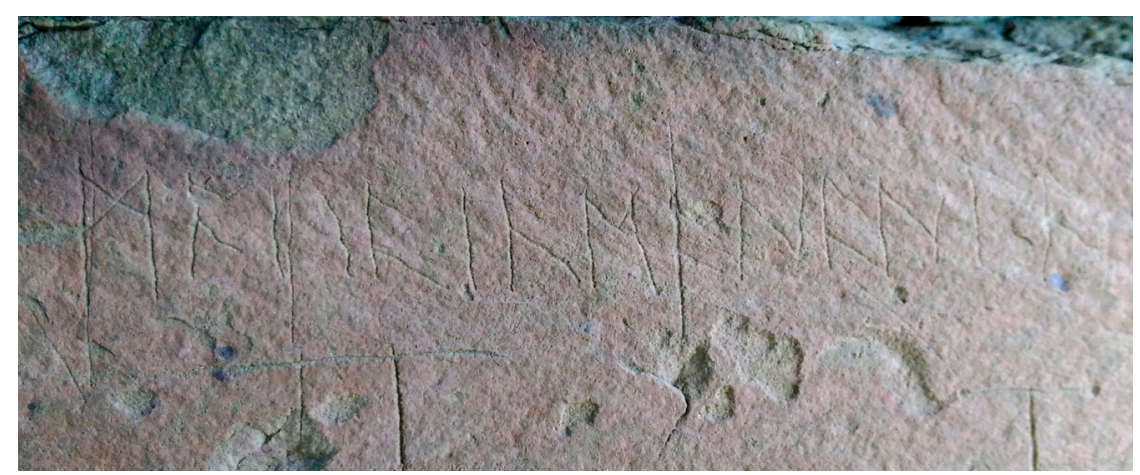

Fig. 3. The inscription from Borwick. Photo: Andrea Freund, 2017.

\section{maurine:hæhwriten:it}

or:

\section{maurine:haswriten:it}

The obvious interpretation would thus be 'Maurine has written it', in modern English, which confirms a modern genesis of this inscription. No other lexical reading suggests itself. All other evidence also supports this conclusion. There is no known instance of the Anglo-Saxon futhorc being used in a genuine Viking Age or medieval inscription in the Northern Isles, and the mixing of Anglo-Saxon futhorc rune forms with older and younger futhark rune forms is inconceivable. The broch's excavation history also supports this conclusion, since before its excavation in 1881, the broch was visible only as a green mound in the landscape and the entrance tunnel would have been filled in and blocked (Watt 1882, 442-50). Neither does a site visit report by the Royal Commission on the Ancient and Historical Monuments of Scotland from 1946 mention any runes in the broch (RCAHMS 1946, 2: 252 f.). The earliest confirmed observation of these runes was made by the archaeologist Robert Waterhouse in 1986 (unpublished, personal communication, 28 April 2017). Thus the runes in the Broch of Borwick represent yet one more case of modern runic inscriptions appearing on freely accessible ancient monuments in Orkney.

\section{Wideford Hill Cairn and Broch of Gurness}

The final two examples from Orkney, namely the modern carvings from Wideford Hill Cairn and Broch of Gurness, will be discussed together because they show some striking similarities. 


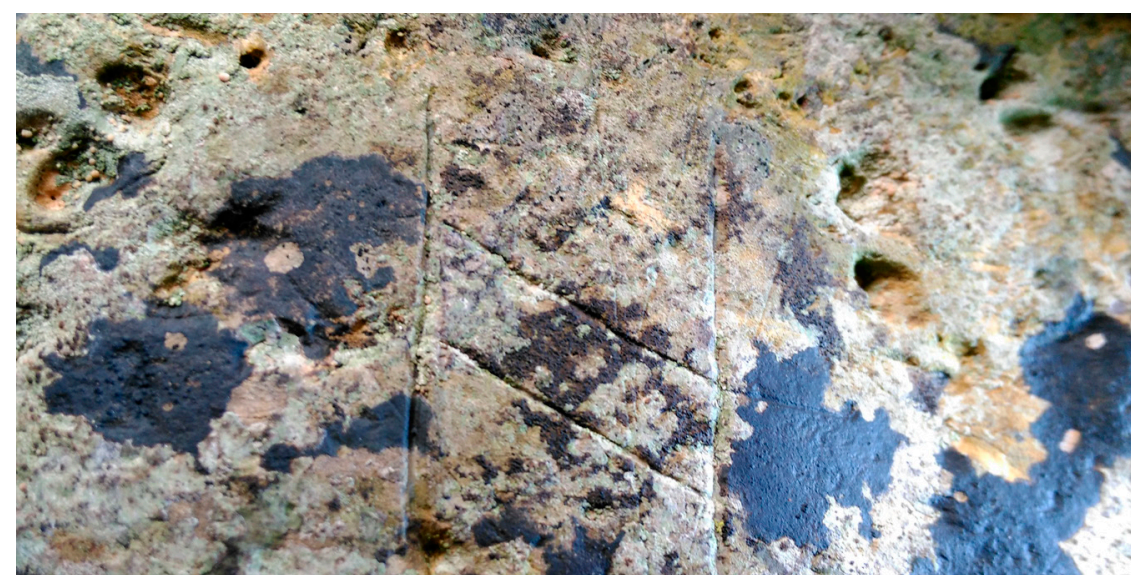

Fig. 4. The inscription at Gurness. Photo: Ragnhild Ljosland, 2017.

A double-barred $\mathbf{h}$, of the Anglo-Saxon type $(\mathbb{N})$, can be seen in the Iron Age broch at Gurness (see fig. 4), and also in the Neolithic chambered cairn at Wideford Hill, both on the Orkney Mainland. This graph type is not part of the Scandinavian younger futhark or mixed medieval futhark common in Norway, but is found in Anglo-Saxon inscriptions from the end of the 600s, and in "South-Germanic" inscriptions of the 500s and 600s (Findell 2016, 155 f.).

Wideford Hill Cairn in St Ola parish dates to c. 2800 B.C. It is situated c. $4 \mathrm{~km}$ from Kirkwall on the lower slope of the hill, overlooking the Bay of Firth, and was opened c. 1849 by George Petrie (Thomas 1851, 124-27). There is no archaeological evidence of Viking Age or medieval activity in or near it. In the modern period, it has been accessible since its excavation in 1849 , and consequently many of the graffiti on its inside walls date to the following decades, although some geometrical patterns may be of Neolithic origin. The cairn is currently freely accessible and unsupervised. The double-barred $\mathbf{h}$ is carved on the wall of the main chamber, $160 \mathrm{~cm}$ above the current floor level. The $\mathbf{h}$ does not overlay any older carvings, nor have newer marks been cut on top. However, in depth, technique or general appearance it does not give the impression of being significantly older than the adjacent graffiti from the 1800s.

The Broch of Gurness in Evie parish lies c. $22 \mathrm{~km}$ from Wideford Hill Cairn. It is currently managed by Historic Environment Scotland and supervised during opening hours in the summer season but freely accessible otherwise. Here, Viking graves and domestic structures from the early Viking 
Age were found in the top layers of the excavation, overlaying the Pictish settlement and the broch (Graham-Campbell and Batey 1998, 127-29). A find of Viking Age runes could therefore potentially be authentic. However, this rune is situated in the right-hand "guard chamber" built into the wall by the main broch entrance, and it is unclear whether this chamber would have been accessible to anyone in the Viking Age. The modern excavation of the Broch of Gurness took place in 1929, after which it was consolidated and prepared for presentation to visitors (RCAHMS 1946, 2: 75-79). The runic inscription at Gurness stands $174 \mathrm{~cm}$ above the current floor level.

The two double-barred $h$-runes are very similar in appearance. The rune at Gurness measures $1.7 \mathrm{~cm}$ wide by $3 \mathrm{~cm}$ high while the rune at Wideford Hill measures $1.8 \mathrm{~cm}$ wide by $3 \mathrm{~cm}$ high. Both have the double branches sloping downward left to right, as is common. One difference is that the $\mathbf{h}$ from Wideford Hill is framed by four clear dots, two on either side, which are lacking at Gurness. The $\mathbf{h}$ at Wideford Hill is also cut much more deeply, as though the carver has spent more time on it.

At Wideford Hill, the $\mathbf{h}$ is accompanied by further runic or rune-like marks on the right, starting $3.3 \mathrm{~cm}$ from the right-hand stave of the $\mathbf{h}$ (see fig. 5). These runes are much smaller and cut more shallowly, and are very difficult to read in their current state. The height of the leftmost of these runes is $1.8 \mathrm{~cm}$. A very tentative reading may be (with alternative readings of individual runes in inscription B provided in a second line):

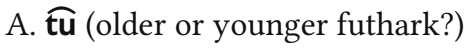

B. gb*mts (older futhark) $\mathbf{r}$ e $*$

On a line directly below the $\mathbf{m}$ (or $\mathbf{e}$ ) in inscription B is a miniature copy of the double-barred $\mathbf{h}$, only $0.7 \mathrm{~cm}$ tall. It is shallow but the detail of the four dots is nonetheless clearly visible.

One cannot of course be certain of the order in which these various runic inscriptions were carved, or whether one or several carvers were involved. It may be that the double-barred $\mathbf{h}$ with dots in the Wideford Hill Neolithic chambered cairn was carved first, since it is the deepest and most carefully cut, and has the detail with the dots. Wideford Hill Cairn was also the first of the two monuments to be excavated. The tiny, shallow double-barred $\mathbf{h}$ in Wideford Hill Cairn copies the larger, deeper one, including the dots. The additional runes may have been the work of the carver who made the small $\mathbf{h}$ as their size and visual impression are very similar. The double-barred $\mathbf{h}$ in the Broch of Gurness also seems to copy the larger one in Wideford Hill Cairn but without the dots. 


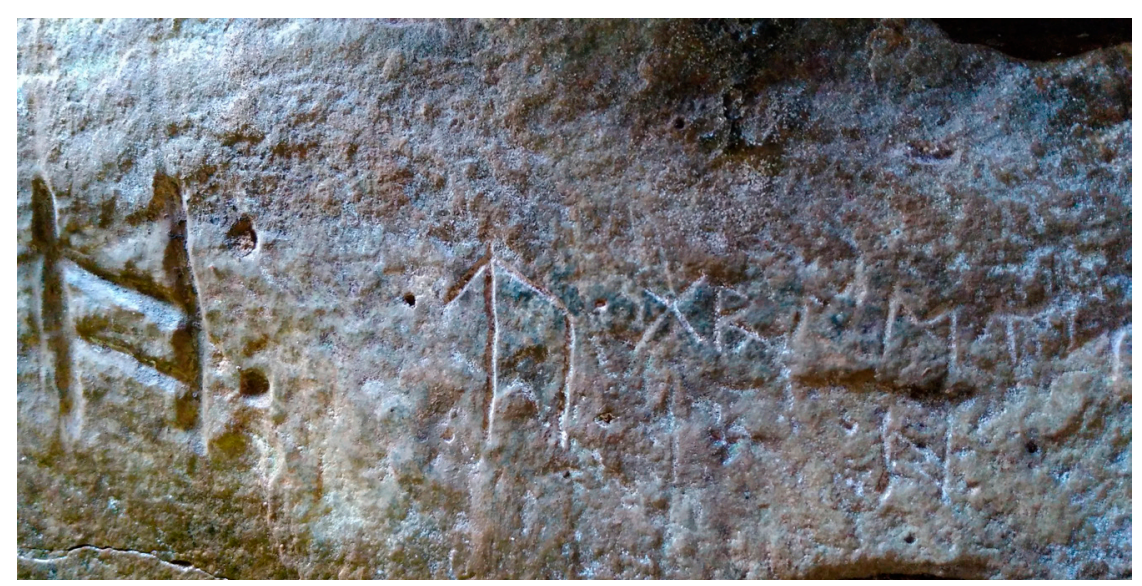

Fig. 5. The inscription from Wideford Hill. Photo: Ragnhild Ljosland, 2017.

\section{Examples from Caithness}

\section{Auckengill}

In 2013, a runic inscription from Auckengill in Caithness was reported in local media, such as the fohn O'Groat fournal (2013). It was brought to the attention of the local community by two families who had spotted the runes on the shore near Auckengill harbour. One of the finders, Anne Richards, stated in an interview with fohn O'Groat fournal that she had been in the habit of walking in the area for forty years but this was the first time she had seen the runes and the rock they were on. She speculated that the large block of stone on which the runes were carved could have broken away from the cliff face and fallen down during a recent storm.

The location is not easily accessible. After a steep descent to the old harbour, the runes are located further along the shore in an area accessible only at low tide. The area is characterised by caves and large blocks of stone that look as though they have at one point fallen from the cliff above, and even at low tide the site is relatively difficult to access. The runes are carved on one of the stone blocks lying outside the mouth of a cave. The rune-carver could only have worked on the runes at low tide and might have had to return over several low tides to complete the inscription.

The runes are large, the tallest staves being about $25 \mathrm{~cm}$ in height. The text is cut along the edge of the big, flat, upwards-facing surface of a large fallen stone block. The runes are all from the older futhark and are read, transliterated and normalised as follows: 


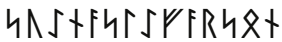

\section{suïnaslïfarson}

\section{Sveinn Ásleifarson}

In this case, it is easy to categorise the inscription as modern. Not only are the runes deeply and evenly cut, and fresh in appearance, but they also look as though they may have been cut by a power tool, or at least a modern tool. One would not expect to find older futhark runes in the far north of Scotland. If Sveinn Ásleifarson is the correct interpretation of the text, one may also note a mismatch between rune form and textual content: the name is in the Old Norse language, and thus not in a language form expected in an older futhark inscription.

A character by the name of Sveinn Ásleifarson is well known from the Orkneyinga saga. He lived in the 1100 s according to the chronology of the saga, and had a farm and drinking hall on the island of Gairsay in Orkney, as well as a castle named Lambaborg in Caithness (Orkneyinga saga, ch. 82 and ch. 105). It is presumably this Caithness connection, and the idea that Lambaborg was located at Freswick, around $4.8 \mathrm{~km}$ from Auckengill, which inspired the rune carving. A Norse settlement was excavated at Freswick Links in the 1990s (Morris, Batey, and Rackham 1995).

\section{Portormin}

Around $48 \mathrm{~km}$ from Auckengill is Portormin, a seaside location in the village of Dunbeath, from which hails the Portormin inscription. This has been known since 1996 and has recently been discussed by Martin Findell (2016). It was found by four schoolchildren who had been "playing by the harbour" and found the stone "above the high water mark" (The Northern Times 2007).

Portormin is close to, but not directly connected with, an early medieval and later Norse site at Ballachly, also known as Chapel Hill, c. $1 \mathrm{~km}$ from the sea (Laing et al. 2013, 265 f., 268, fig. 4: site map, which shows Portormin in relation to Ballachly). In the same year as the Portormin runic inscription was found, a decorated stone from the 600 s was found by the landowner at Ballachly (ibid., 265).

Perhaps more crucially, Portormin is also in the close vicinity of Dunbeath Primary School, which the four finders attended.

The evidence for the Portormin inscription's being modern is somewhat less conclusive than for Auckengill, but Findell (2016) notes among other things that graph types and language form cannot easily be reconciled. The combination of graph types is odd, containing runes belonging to 


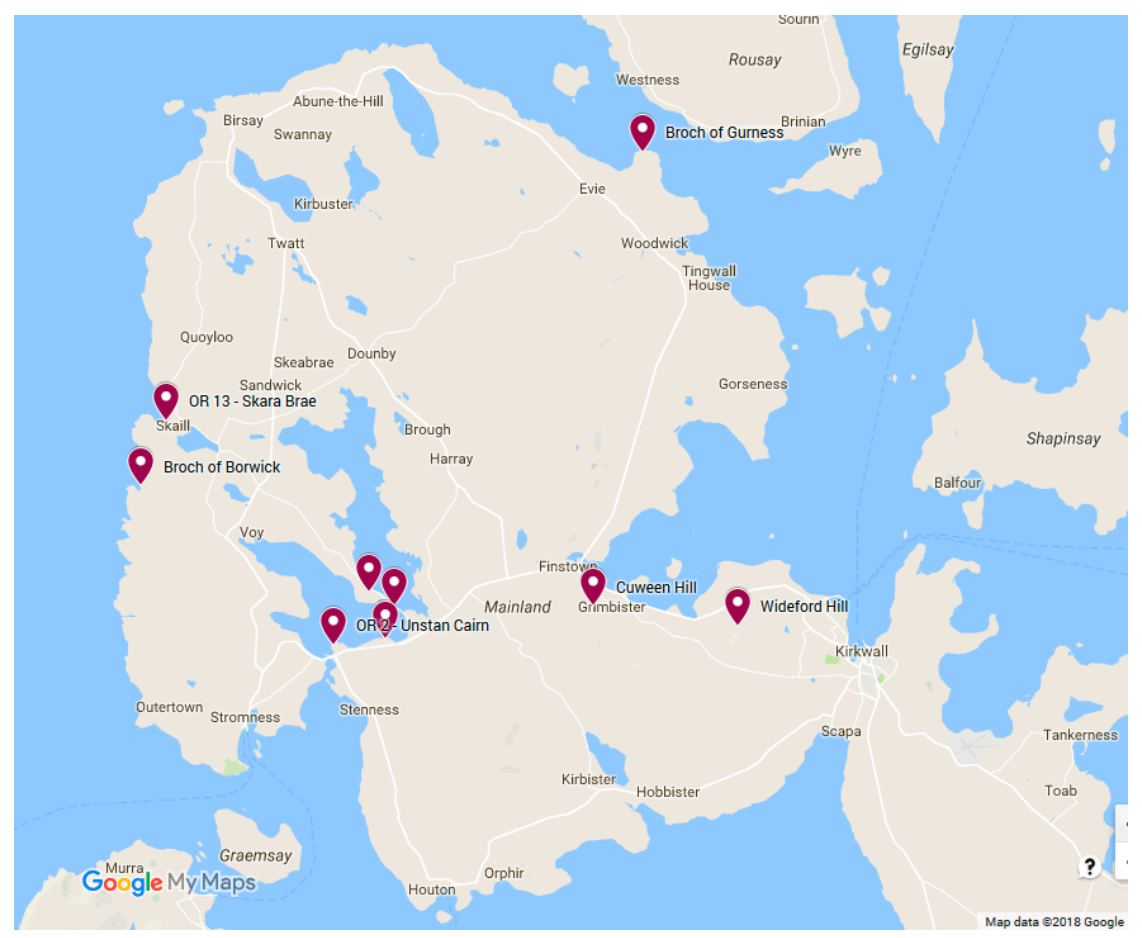

Map 1. Distribution of modern runic inscriptions in Orkney. () Google. Distribution data: Andrea Freund, 2018.

several rune-rows, of which one is diagnostic of the Anglo-Saxon runerow and one of the older futhark, neither of which would be expected in the far north of Scotland. Findell admits that it is impossible to reach a firm conclusion regarding the modernity of the Portormin runestone but judges that the total balance of probabilities favours a modern origin. The present authors agree with Findell's conclusion and consider this inscription most probably modern.

\section{Assessment of the material}

The sheer volume of material, and the necessarily fragmentary way of reporting it, makes it plausible that there could be many more examples of modern runic inscriptions in the region. There is, however, no coordinated effort to record them, so it is conceivable that inscriptions are discovered, discarded as modern, and then simply not reported to the academic community before being forgotten again. 
A look at the geographical distribution of modern runic inscriptions in Orkney (see map 1) shows that, to our current knowledge, the phenomenon is limited to the West Mainland of the archipelago, centering on the World Heritage Site. This area is the focus for heritage tourism in Orkney so the concentration of the phenomenon there might indicate visitors leaving their marks on the island. However, the number of examples might also reflect a bias in discovery due to archaeological focus on its sites. Potentially, modern inscriptions on the smaller Orcadian isles have simply not yet been noticed or reported.

\section{What makes a forgery?}

Before assessing the phenomenon of "new" runic inscriptions in Orkney and Caithness, it is important to establish the right terminology. Calling them "forgeries" implies a sense of fraud and suggests an attitude of reproach (Oxford English Dictionary). In many of the cases described, it seems that the runes were not carved with any intention to deceive, or at least not with fraud as the primary objective. In the case of other known forgeries of historic objects or texts, we can usually identify a clear agenda: saga manuscripts were forged with a view to selling them to make money, medieval literary histories fabricated to raise national self-awareness or prove a certain culture's antiquity (Jorgensen 1977; Rayfield 2012). Both the commercial and political motives which are so typical of historic forgeries are absent in the runic inscriptions - they are neither sold, nor do they make for a compelling narrative. On the contrary, many of them cannot even be read in any way that makes sense.

Findell $(2016,160)$ argues strongly against calling the runic inscription a forgery or fake when discussing the Portormin inscription: "Perhaps the most pressing question surrounding this inscription is that of whether or not the inscription is 'genuine' - or better, the question of whether or not it is modern (we should refrain from labelling an inscription as a fake or a forgery unless there is some indication that the carver's intention was to deceive)."

The question is then whether these carvings should be regarded as runic forgeries at all, or rather called something akin to modern runic doodles. To assess this, it is worth looking at the different phases of modern rune carving in Orkney and contrasting the phenomenon with other welldocumented and researched instances of the modern use of runes. 


\section{Phases of modern rune carving in Orkney}

The first wave of post-medieval interest in runes in the region was sparked by James Farrer's 1861 discovery of the inscriptions in Maeshowe (Farrer 1862). These were frequently discussed in The Orcadian which means that locals too would have become aware of the importance of their runic heritage during this period (see for example Farrer 1861; The Orcadian 1861; Rafn 1861). In the following years, exciting tales about Vikings were constructed from the readings of the inscriptions, with George Stephens's version offering "an atmospheric picture of the old north ... and a handful of forgotten Vikings whose names and faceless presence lent substance to the world of their more celebrated contemporaries" (Wawn 2000, 235). This romantic view of runes telling tales of glorified ancestors could easily have served as motivation for the earliest copycats, although interest in runes appears primarily a pastime of learned gentlemen in the mid-1800s and there are no inscriptions in the present corpus which can be securely dated to this period.

There are, however, some inscriptions that appear to have been carved in the late 1800 s or first half of the 1900s, such as OR 2 and OR 5. During this period, a romantic and nostalgic view of the medieval past began to permeate popular culture and played an important role in the negotiation of national identities (Matthews 2015, 31-35). This gave rise to the idea of medieval "authenticity as a search for cultural origins" (Clements 2014, 26). Thus, engaging with runes provided a means of connecting Orcadians to their particular local heritage. In post-war Orkney, there appear to have been a few decades of hiatus in modern rune carving. The present authors would suggest this is connected with the generally reduced public and media interest in the Norse past during this period (cf. Arnold 2014, $170 \mathrm{f}$.).

The next dateable inscription presented here is OR 13 from 1982 when interest started to rise again, with the inscription from Borwick most likely belonging to this phase, too.

A large number of the modern inscriptions in the corpus presented above most likely date from the later 1900 s to the present, when medievalisms, including Vikings and runes, had become omnipresent in mass media (Elliott 2017, 38-54, and Arnold 2014, 171). From the 1990s, the Internet with its number of "runic translator" tools made it easier than ever for non-runologists to write in more or less credible runes. At the same time, tourism in Orkney grew exponentially, especially since the 1999 designation of the Heart of Neolithic Orkney UNESCO World Her- 
itage Site. This combination of popular interest in the medieval past and Orkney's heritage along with the increasing ease of using runes for carving may have been the underlying inspiration for a number of the latest modern inscriptions, including for example the recent addition in Unstan. The two Caithness examples would also belong to this phase, combining a renewed interest in the Norse past and the availability of ample information to create an almost plausible runic inscription.

The Kensington runestone: a model for understanding the phenomenon?

The most famous runic hoax is possibly the Kensington runestone, and because this case has been widely discussed in the field of runology it is interesting to compare the terminology used for this runestone to see if it might be helpful in discussing the phenomenon of modern runes in Northern Scotland. The runestone was purportedly discovered in 1898 in Kensington, Minnesota, firmly embedded in tree-roots, by a farmer of Swedish origin. However, the inscription was quickly discarded as nonmedieval by specialised academics (Williams 2012, 4-7). A 1960s study of all the evidence came to the conclusion that the inscription must be a hoax from the 1800s (Blegen 1968).

Yet this stone is still causing considerable debate and passionate arguments among runologists as well as other interested people (see for example Nielsen 2001 and Knirk 2001). In recent decades, the controversy has continued to simmer mainly between runologists on the one side, arguing the stone was a forgery, and amateurs or academics with little expertise in runology and Old Norse linguistics on the other, claiming the inscription might be genuinely medieval (see Knirk 1997). In addition, the Kensington runestone is still the world's most famous runestone, despite all the doubts about its authenticity (Williams 2012, $7 \mathrm{f}$.).

It is unclear who carved the inscription and what the intention in producing the Kensington runestone was. Was it, as Mats G. Larsson (2010) suggests, merely a practical joke gone wrong, or did it have deeper underlying motives? An examination of the situation of Scandinavian settlers in Minnesota at the time of its likely carving might shed some light: they had only recently arrived, suffered from a lack of acceptance and prejudice and thus were eager to demonstrate how their ancestors had contributed to world history (Michlovic 1990, 105). It is conceivable that, like forgeries of historic documents to strengthen a sense of national identity and pride in a heritage, the Kensington runestone falls into a category of conscious forgery with no financial intention. 
In his recent analysis of the object, Henrik Williams reaches the conclusion that it is most likely an inscription from the 1800 s but nevertheless argues against calling it a fake $(2012,19 \mathrm{f}$.):

First of all, the words believe and fake are not scholarly terms; scholars establish the evidence and what conclusions the evidence indicates. In this case, the evidence supports the conclusion that the KRS is a nineteenth-century inscription. Second, a fake is something done with the intention to deceive. There are plenty of runestones in Scandinavia carved in the recent centuries which cannot be called fakes, and as for the KRS we do not know what the intention of its carver originally was. Third, the issue is so much more complex than just the question of fake or not.

Consequently, Williams argues that the inscription, even if not medieval, is not worthless. It has value as a "catalyst of scientific and scholarly debate", an "instrument in creating identity" and can aid in learning about "uses and abuses of historical objects" (ibid., 20). This view could be useful in assessing modern runic inscriptions in Caithness and Orkney, too.

Of course, there are considerable differences: the inscription on the Kensington runestone is substantially longer than any of the carvings examined here. It furthermore makes linguistic sense, which the Scottish examples often do not. In addition, the passionate debates surrounding the Kensington runestone are absent in Scotland. However, what unites all these cases is that there is no indication of a fraudulent intent. Perhaps the Scottish inscriptions could, and should, be viewed as expressions of pride in the region's Norse heritage, just as the Kensington runestone may document pride in a perceived Scandinavian ancestry. At least the fact that some are more or less crude copies of the Maeshowe runes supports this idea.

\section{Modern use of runes in Orkney: engaging with the past}

There is little enlightening information on the motivations of the modern rune-carvers in Orkney and Caithness in their inscriptions, and they rarely come forward to talk about them. However, the related phenomenon of modern professional rune carving in Scandinavia has been studied in detail (Petersson 2010). This study's findings show that the usually male runecarvers there perform their craft very differently to the carvers who made the inscriptions examined in this article. In Scandinavia, new runestones are usually crafted in public, as a performance in Viking markets or to be displayed as memorials in public spaces. There is no attempt to conceal 
their modern origin (ibid., 72-82). On the contrary, it is the very act of carving runes, perceived as an ancestral script, which enables the carvers to contextualise the past, so that the "act of carving and erecting rune stones today is a kind of time travel to identity" (ibid., 83-85). Possibly, rune-carvers of today in Orkney and Caithness also perceive this act of carving runes as a connection to their ancestors, a motif which may be strengthened by carving on ancient monuments.

As Barnes observes, the interest in runes is particularly strong in Orkney, and this results in many different commercial uses of runes, from signage at Kirkwall Airport to rune-inscribed jewellery and chocolate wrapping paper (Barnes 2012, 135-43; Ljosland 2014). The Orcadian public must thus be more aware of runes than the average Scottish or British layperson, which again might result in runes being used for graffiti or doodles more commonly than elsewhere.

Another striking fact about the runic inscriptions that have been discussed in this article is that in Orkney they frequently appear on or in ancient monuments, be it Neolithic chambered tombs or Iron Age brochs. This makes a comparison with the famous medieval runic graffiti in Maeshowe inevitable. One might wonder whether people, either Orcadians or tourists, feel entitled to replicate these celebrated inscriptions. After all, the Maeshowe runes are omnipresent in Orkney and particularly visible at sites frequented by tourists: they are on postcards, in artworks at the airport and on a display at the Scrabster ferry terminal which reads: "Follow in the footsteps of the 12th century Vikings by visiting Maeshowe and seeing their Norse runic inscriptions which are considered to be one of the finest archaeological achievements of prehistoric Europe." While this phrase shows a somewhat distorted understanding of runic writing, it is the first information many visitors receive and it is certainly conceivable that this glorification of the intrusion into ancient monuments and the carving of runic graffiti there could have inspired some modern copycats.

Another factor contributing to the prevalence of modern runic carvings might be found in the geology of Orkney: carving into the soft sandstone is easier than in many other places where harder stone types dominate. Therefore, in some quarries and stone-built structures one can now find hundreds of names and dates ranging from the 1700s to modern times. Antonia Thomas explains these carvings as "declarations of identity in a new age of literacy and leisure" (2016, 40-42).

Thus, Orcadian culture, with both its use of runes as a common heritage and its tradition of carving identity markers at prominent sites within Orkney's archaeological landscape, results in a unique combination of these 
two traits which offers a reasonable explanation for the wealth of modern runic inscriptions there. The two modern examples from Caithness included in the inventory might be explained by the close geographical proximity to Orkney as the centre of this phenomenon.

\section{Conclusion: a distinct new use of runes in Northern Scotland}

Just as Bodil Petersson argues for the modern runestones of Scandinavia being perceived as authentic and monuments in their own right $(2010,82)$, the modern runic inscriptions in Orkney and Northern Scotland cannot be dismissed as simple forgeries either.

One interesting feature which became obvious during the present study is the case of the Orcadian twig runes: there are six potential cases in the corpus outside Maeshowe. Of these OR 2 and OR 13 are most likely of modern origin and OR 5 and OR 7 also raise considerable doubt as discussed above, while for OR 1 Stackrue, it is not entirely clear if what appears as a twig rune is really intended as such or as a bind-rune or not runic at all (cf. Barnes 2003, 6 f.). This means that, outside of Maeshowe, medieval Orcadian rune-carvers did not use twig runes significantly more frequently than elsewhere. In contrast, modern Orcadian rune-carvers are more inclined to use twig runes than their medieval counterparts. The present authors would suggest that for a possible inspiration one needs look no further than Maeshowe. In Orkney, countless images of the "mysterious" twig runes inside the tomb are available and an interpretation panel outside the site even explains how the cipher functions, making it fairly easy for modern lay carvers to recreate it. It is worth noting that the visual effect of twig runes can be easily achieved by carving a stave with various twigs, which may not necessarily result in any lexical words but may look "rune-like", without the carver having to learn any runes (as suggested by an anonymous peer reviewer of this article, whom the authors thank).

As this article has shown, newly carved runic inscriptions can cause considerable difficulty for runologists working in Orkney and Northern Scotland. In some cases, decades passed before they could be confirmed as recent carvings. In other cases, absolute certainty about their age may never be reached. One issue is the lack of a practical way of collecting information on these carvings, comparable to the Scandinavian Runic Text Database. It might be a sensible solution to collect and store information in a single database on any discovery of a modern runic inscription that risks being misinterpreted as Viking Age or medieval. This database should then 
be made accessible to the academic community to enable more research on the topic, and to avoid any object's being wrongly classified as a newly discovered potentially Viking Age or medieval inscription. In addition, a renewed effort should be made to educate the public about the value of the original runic inscriptions, how and where to access them-and convey the message that defacing ancient monuments with new runic carvings is not acceptable.

To conclude, it must be stressed that modern inscriptions merit research as a phenomenon in their own right. They show an interest and engagement with the Viking and medieval past, which in turn offers runologists a positive way of engaging with communities.

\section{Bibliography}

Arnold, Martin. 2014. "Myth.” In Medievalism: Key Critical Terms, ed. Elizabeth Emery and Richard Utz, 165-72. Medievalism, 5. Cambridge.

Ashmore, Patrick J., and Ingrid Sanness Johnsen. 1984. "A Runestone from Skara Brae, Orkney." Medieval Archaeology 28: 183-85.

Barnes, Michael P. 1994. The Runic Inscriptions of Maeshowe, Orkney. Runrön, 8. Uppsala.

— . 2003. "Runic Tradition in Orkney: From Orphir to the Belsair Guest House." In The Faces of Orkney: Stones, Skalds and Saints, ed. Doreen J. Waugh, 4-17. Scottish Society for Northern Studies, Publications, 11. Edinburgh.

—. 2012. Runes: A Handbook. Woodbridge.

Barnes, Michael P., and Raymond Ian Page. 2006. The Scandinavian Runic Inscriptions of Britain. Runrön, 19. Uppsala.

Blegen, Theodore C. 1968. The Kensington Rune Stone: New Light on an Old Riddle. St. Paul, MN.

Clements, Pam. 2014. "Authenticity." In Medievalism: Key Critical Terms, ed. Elizabeth Emery and Richard Utz, 19-26. Medievalism, 5. Cambridge.

Downes, Jane, et al. 2013. "Investigating the Great Ring of Brodgar, Orkney." In Building the Great Stone Circles of the North, ed. Colin Richards, 90-118. Oxford.

Düwel, Klaus. 1998. "Geheimrunen." In Reallexikon der Germanischen Altertumskunde, founded by Johannes Hoops, ed. Heinrich Beck et al., 565-68. 2nd ed. Berlin.

Elliott, Andrew B. R. 2017. Medievalism, Politics and Mass Media: Appropriating the Middle Ages in the Twenty-first Century. Cambridge.

Farrer, James. 1861. "Excavations at Stenness." The Orcadian, 24 July 1861, 3.

- 1862. Maes-Howe: Notice of Runic Inscriptions Discovered during Recent Excavations in the Orkneys. Edinburgh.

Findell, Martin. 2016. "The Portormin (Dunbeath) Runestone." Futhark: International Journal of Runic Studies 6 (2015): 153-70. 
Graham-Campbell, James, and Colleen E. Batey. 1998. Vikings in Scotland: An Archaeological Survey. Edinburgh.

Griffiths, David. 2015. "Status and Identity in Norse Settlements: A Case Study from Orkney." In Maritime Societies of the Viking and Medieval World, ed. James H. Barrett and Sarah Jane Gibbon, 219-36. Leeds.

Jesch, Judith. 1991. "New Finds from Orkney." Nytt om runer 5 (1990): 13-14.

fohn O'Groat fournal 2013 = "Experts Cast Doubt on Auckengill 'Runes'." Fohn O'Groat fournal, 1 May 2013. Available at: https://www.johnogroat-journal. co.uk/news/experts-cast-doubt-on-auckengill-runes-108515/（accessed 21 April 2017).

Jorgensen, Peter A. 1977. “'Hafgeirs saga Flateyings': An Eighteenth-Century Forgery." The fournal of English and Germanic Philology 76: 155-64.

Knirk, James E. 1997. "Kensington Runestone [review].” Scandinavian Studies 69: 104-05.

—. 2001. "Umlauted Runes on the Kensington Runestone." Scandinavian Studies 73: 210-14.

Laing, Lloyd, Edward Oakley, Anne E. Sassin, and Imogen Tompsett. 2013. "Excavations at the Early and Later Medieval Site of Ballachly, Dunbeath, Caithness, 2007-10." Proceedings of the Society of Antiquaries of Scotland 143: 265-302.

Larsson, Mats G. 2010. "Vem ristade Kensingtonrunstenen?” Saga och sed 2010: 59-68.

Ljosland, Ragnhild. 2014. "Communicating Identity: The Modern Runes of Orkney.” Studia Historyczne 3 (2013): 412-30.

Matthews, David. 2015. Medievalism: A Critical History. Cambridge.

Michlovic, Michael G. 1990. "Folk Archaeology in Anthropological Perspective." Current Anthropology 31: 103-07.

Morris, Christopher D., ed. 1985. "Skaill, Sandwick, Orkney: Preliminary Investigations of a Mound-site near Skara Brae.” Glasgow Archaeological fournal 12: 82-92.

Morris, Christopher D., Colleen E. Batey, and D. James Rackham. 1995. Freswick Links, Caithness: Excavation and Survey of a Norse Settlement. Inverness.

Nielsen, Richard. 2001. "The Kensington Runestone." Scandinavian Studies 73: 209-10.

The Northern Times 2007 = "Harry Potter and the Viking Rune Stone." The Northern Times, 28 Dec. 2007.

The Orcadian 1861 = "The Antiquarian Discoveries in Orkney." The Orcadian, 3 Aug. 1861, 3.

Orkneyinga saga. In Orkneyinga saga, Legenda de sancto Magno, Magnúss saga skemmri, Magnúss saga lengri, Helga páttr ok Úlfs, ed. Finnbogi Guðmundsson, 1-300. Íslenzk fornrit, 34. Reykjavík, 1965.

Oxford English Dictionary = "forgery, n." In OED Online. http://www.oed.com/ view/Entry/73317?redirectedFrom=forgery (accessed 31 Jan. 2017). 
Petersson, Bodil. 2010. "Travels to Identity-Viking Rune Carvers of Today." Lund Archaeological Review 16 (2009-10): 71-86.

Rafn, Carl C. 1861. "Runic Inscriptions in Orkney.” The Orcadian, 14 Sept. 1861, 3. Rayfield, Donald. 2012. "Forgiving Forgery." The Modern Language Review 107. 4: xxv-xli.

RCAHMS 1946 = The Royal Commission on the Ancient and Historical Monuments of Scotland. Twelfth Report with an Inventory of the Ancient Monuments of Orkney and Shetland. 3 vols. Edinburgh.

Rosenfeld, Hellmut. 1984. "Die germanischen Runen im Kleinen Schulerloch und auf der Nordendorfer Bügelfibel A." Zeitschrift für deutsches Altertum und deutsche Literatur 113: 159-73.

Scandinavian Runic Text Database (Samnordisk runtextdatabas). Institutionen för nordiska språk, Uppsala universitet. Version 3.1 (2014). http://www.nordiska. uu.se/forskn/samnord.htm.

Thomas, Antonia. 2016. "Written in Stone: Geology and Graffiti in Orkney." Stravaig (online journal of the Scottish Society for Geopoetics) 5: 40-42.

Thomas, Frederick W. L. 1851. "Account of some Celtic Antiquities of Orkney, including the Stones of Stenness, Tumuli, Picts Houses, \&c., with Plans.” Archaeologia 34 (1851-52): 88-136.

Watt, William G. T. 1882. "Notice of the Broch known as Burwick or Borwick, in the Township of Yescanabee and Parish of Sandwick, Orkney." Proceedings of the Society of Antiquaries of Scotland 16 (1881-82): 442-50.

Wawn, Andrew. 2000. The Vikings and the Victorians: Inventing the Old North in Nineteenth-Century Britain. Woodbridge.

Williams, Henrik. 2012. "The Kensington Runestone: Fact and Fiction." The Swedish-American Historical Quarterly 63: 3-22.

Züchner, Christian. 2006. "Überlegungen zum Alter der Felsbilder im Kleinen Schulerloch.” In Das fupark und seine einzelsprachlichen Weiterentwicklungen: Akten der Tagung in Eichstätt vom 20. bis 24. Fuli 2003, ed. Alfred Bammesberger and Gaby Waxenberger, 380-84. Ergänzungsbände zum Reallexikon der Germanischen Altertumskunde, 51. Berlin. 